\title{
Environment-Friendly Natural Turf for More Comfort for Users: A Review
}

\author{
Moumita Malakar ${ }^{1}$, Pinaki Acharyya ${ }^{2}$ and Sukanta Biswas ${ }^{3}$. \\ Department of Horticulture, University of Calcutta, 51/2, Hazra Road, Kolkata- 700019.
}

\begin{abstract}
Turf grass is a chart-topping and the predominant form of vegetation in many cities and suburbs. Rapidly expanding urbanization and unceasing enlargement of population structure causing shrinkage of defoliated area profoundly diming the usefulness of environment friendly natural turf and making its management unbearable. Therefore, dire need is to investigate extensively on turf science counting turf grass breeding, genetics, cultivar evaluation and physiology. Among multitudinous utilitarian conveniences soil erosion prevention, dissipation of rain drop energy, adherence of soil by roots, infiltration of precipitation, purification of infiltrated water, recharge of ground water and last but not the least is the reformation of soil structure being supplemented organic matter uninterruptedly are predominantly pronounced. For salubrious territory green patched zone comprised of natural turf grasses aid of their above-ground network by dense canopy of leaf blades and substantial fibrous root system below become obligatory since dust eradication, diminished clay disintegration, infiltration and replenishment of natural water-table universally perpetrated by them. It also furnishes feeding ground for fauna collaterally engendered invulnerable playing surface for children, adults and athletes. As eye-soothing and biodegradable grass-based turf proffer superior recreational facilities, an insistent and peremptory plea on behalf of prosperous urban population for their domain is arriving but few stumbling blocks concerning maintenance hindering this inordinate issue. Hence, we have endeavored to accomplish this work aiming to review relevant research and summarize findings. Owing to turf grass's manifold advantages in both reclamation and recreation launching of new technologies and management strategies and analogously potential purchase and installation of natural turf will be the most fiscally and environmentally sound decision for the decision-makers.
\end{abstract}

Keywords: Environment-friendly, infiltration, recreational, turf grass, urbanization.

\section{Introduction}

From the literal point of view the word 'turf' refers to 'cover something with specific substance' whereas from the horticultural point view it can be explained that upper stratum of soil bound by grass or other low growing plants which form a kind of mat. In recreational contexts, the different specialized names 'lawn', 'pitch', 'field' or 'green' are used depending upon the situation and the continent [49]. The traditional way to develop a turf in a landscape is with grass of different types as would serve the functional purpose of the same. The word 'turf' can also be used as a synonymous word of 'Lawn'. Lawn is a cognate of llan which is derived from the common brittonic word landa that originally means heath, barren land, or clearing. A lawn can be explained as an area of aesthetic and recreational land planted with grass or other durable plants of having more or less of same functional use [15]. However, in strict sense of the word used in horticulture is to donate a piece of land composed only with grass species subjected to weed and pest control being aimed to maintain its green color and kept under regular mowing as well as other maintenance to ensure an acceptable longevity and functional purpose in residential, commercial and recreational areas [13]. Low ornamental meadows in natural landscaping styles are a contemporary option of a lawn. Ordinarily, grass in landscape is referred to by most people as a lawn; grass if football field of golf course, however, is referred to as turf. The term 'Lawn', referring to managed grass space, dated to no earlier than the $16^{\text {th }}$ century. In the early $17^{\text {th }}$ century, the closely cut 'English' lawn was born. Till the middle of twentieth century grasses were the only materials for turfing in home areas and playing fields.

According to scientists, rapid change of our climate has major consequences on flora and fauna - and for human health in particular. Increased air pollution can be reduced by fixing greenhouse gases from the air in the soil with aid of natural grass. The most interesting fact is that the annual oxygen production and carbon dioxide fixation from one hectare of grass exceeds that of one hectare of rain forest area [6]. In recent year's development of new and innovative grass cultivars help to cope them with varied agro-climatic condition as many high-tech coated ryegrass seeds are available which boost their germination at lower temperatures (> $3.5^{\circ} \mathrm{C}$ ) and extend the growing season of grass with brilliant color [20]. In addition to its positive environmental characteristics, natural grass is a safe product to play on. It absorbs heat from sun on the pitch, the risk of injury is very low, it's cheap and, last but not least, it's self-repairing. Natural grass is renowned in respect of sustainability and reducing the environmental impact is much concerned in modern era. The emotional value of 
grass - its feel, smell, the way it responds, its cooling effects in hot weather, and the considerably reduced risk of injury - the benefits are clear to see. With the increasing popularity of youth sports, especially soccer, and the necessity for building and more athletic fields, many communities are considering construction of artificial turf in athletic fields [1]. Poor establishment of natural turf in arid regions for playing fields as well as for home landscapes and continuous rationing of nutrients for turf grasses harbor synthetic turf though high maintenance and low durability should key concern [30]. To make physically and environmentally sound decisions regarding potential purchase and installation of artificial turf or natural grass in home landscaping and play grounds wide range of issues and concerns are needed to be considered. The key objectives of the present study is to concern developers, entrepreneurs and the landscapers for adopting natural turf appropriate for any situation-based decision than artificial grass particularly destroying our required fossil resources involved in the manufacture of it indeed a heavy burden on the environment.

\section{A Cursory Background of Lawn}

The word "laune" is first attested in 1540 denoting grassed enclosures within early medieval settlements used for communal grazing of livestock, as distinct from fields reserved for agriculture. Lawns became popular with the aristocracy in northern Europe from the middle ages onward. In the 'Illustrated History of Gardening', Huxley stated that a comprehensive delineation to prepare a turf arrived from a popular work called 'Opus ruralium commodorum',' or 'The Advantages of Country Living',' by Petrus de Crescentius where digging out all weeds and roots, scalding the soil with boiling water inhibiting further weeds germinating followed by laying turf brought in from the wild. Aid of wild flowers or other durable plants such as clover these first lawns were plastered and short-heighted hillocks of turf were created for seating, which were sometimes planted with aromatic herbs such as chamomile. In the early 17 th century, lawns began to be mown accomplished by scythe, with shears used for edging more frequently. The 18th century brought the design of even more expansive parks and gardens in the estates of wealthy landowners while the invention of the cylinder or reel mower in 1830 by Edwin Beard Budding [48] made lawn maintenance easier to achieve, but it wasn't wide spreaded in the suburbs in the early 1900s when lawns became prevalent outside of parks, golf courses, and large estates. In modern America, lawns have become a cultural touchstone, a symbol of suburban living, and the passion of many homeowners [3].

\section{Rudimentary Functions of Natural Turf in Landscape}

Turf has ornamental value as it enhances the beauty of home adjacent areas where it is established. Not only in the home landscape, it has wholesome beautification value in public parks and commercial building sites. While home lawns help to create a serene and beautiful landscape, turf grass provides a great deal more than a lush outdoor carpet of the property. Owing to their manifold advantages turf is North America's largest agricultural crop [4].

Natural turf is an integral part of enjoyable activities such as sports. Many sports surfaces including football ground, tennis courts, golf courses athletic and basketball fields are covered with turf grass [25]. It is also used in community and home playgrounds. Natural turf brings a multitude of benefits, from its unbeatable environmental credentials conclusion drawn by Plantum (the trade association for organizations in the natural turf sector in the Netherlands) while it remains the natural choice for football, sports and playing surfaces' by the European Seed Association (ESA) [31].

Among natural turf's multitudinous functions the foremost is the environmental benefits such as erosion control, dust filter, climate control etc. To prevent potential soil loss, turf grass is used on slopes along the roads, ponds and other areas that are prone to soil erosion. In regard to ornamental role, the visual quality which includes texture (fine or coarse), color (pale green or rich green), growth habit and other characteristics are very important. While used in sports fields the quality is adjudged on the basis of resistance to wear i.e. capacity to re-bind after use or its elasticity. Durability or colonizing habit of grasses is valuable criterion at the time of utilizing in the sports field also [7].

\section{Environmental Benefits of Natural Grass}

Grass plants capture and use greenhouse gases, thereby counteracting the climate change since rapid change of climate has huge impact on flora, fauna and human health. Reduction of Carbon-di-oxide $\left(\mathrm{CO}_{2}\right)$ in the atmosphere is of utmost importance in this fatal process. Concerning this issue natural turf traps air pollution and engenders much of the oxygen $\left(\mathrm{O}_{2}\right)$. It was informed by 'The Lawn Institute' that just one acre of grass can absorb hundreds of pounds of fossil-fuel created sulfur dioxide in a single year [33]. It was reported that both forest areas as well as grass land has equal contribution in protecting our environment [19]. Grass also takes in hydrogen fluoride, peroxyacetyl nitrate and particulate matter in our atmosphere, emit initially from the burning of carbon based fuels the worst group of atmospheric pollutants into their leaves and break them down [35]. Research findings revealed that grasses trap an estimated 12 million tons of dust and dirt released annually into 
the atmosphere. So significantly grassed areas lower the levels of atmospheric dust and pollutants. It also serves as a natural air-conditioner as an average sized healthy lawn has the cooling effect of 70 tons of air conditioning while its a natural dust filter too [36]. Turfgrass is the best defense against soil erosion. They bind the soil by their extensive root system which under congenial condition may be over 300 miles. It offers a very efficient and inexpensive erosion control function being intercepted raindrop before they disturb the soil. Turf also acts as a barrier that deters chemicals from entering into the soil profile [37]. One of the major causes of the growing water quality problem is runoff of contaminants from hard surfaces, such as roads and parking lots. Being prevented water run-off turf assists to recharge the ground water table by water percolation. Turfgrass purifies the water as it leaches through the root zone and down into our underground aquifer where soil microbes aid in breaking down chemicals into harmless materials. The biology of turfgrass makes lawns a near ideal medium for the biodegradation of all sorts of environmental contamination [36]. Noise pollution, a growing problem in urban areas can be abated by natural grasses absorbing excessive sound to curtail the level. For example, grassed slopes beside lowered expressways reduce noise 8-10 decibels [33]. Traffic, both vehicular and pedestrian, is directed by lawn barriers in areas of heavy movement of people and on roadsides and medians. Fire retardation also by buffer areas of well-maintained lawn grass around buildings is good insurance [33].

Grass is vital to carbon sequestration, the process of removing carbon from the atmosphere and depositing it in the soil reservoir. This means that, hectare for hectare turf grass will sequester more carbon into the soil each year than woodland [31]. For instance, a football pitch measuring around 10,000sq $\mathrm{m}$ or one hectare is capable of capturing and sequestering an average of 12 tonnes of $\mathrm{CO}_{2}$ per year. Conversely, the artificial yarns or fibers that make up artificial turf are manufactured predominately from petrochemicals - one of the main contributors to global warming [18]. One of the strongest arguments for installing natural turf is that it is by far the most sustainable, environmentally and carbon-friendly option. Installation and preservation of natural turf pitches by many clubs and municipalities can be a viable option to become carbon neutral. Every artificial pitch must be transfigured into natural green pitch inevitably to compensate greenhouse gas effects produced and neutralize the carbon [8]. Indeed, 2010 research conducted by the University of California, Berkeley in the States concluded that artificial turf releases more greenhouse gases in its production, transportation and processing than the maintenance of natural turf ever would [38]. Another investigation on the carbon sequestration potential of managed turf grass in the United States concluded that well-managed turf grasses cut regularly at the appropriate height followed by feeding by nutrients without hampering their root zone actively pull pollutants from the air and as a resultant effect sequester significant amounts of carbon [31].

\section{Natural Turf and Artificial Turf- Separating Illusion and Facts}

Besides public, political and personal considerations several practical, climatic and financial factors should also contemplated while determining whether installing artificial turf or renew natural turf pitches. Natural turf has notable contribution towards the society collaterally to create better living condition. There's no denying that the arguments are compelling on both sides and it may seem like a tough decision [16]. Football's international governing body, FIFA itself has lent its support to artificial turf aiding product development and giving rise to its more accepted, widespread use. Indeed, the technology has improved overcoming many problems associated with early-generation pitches [17]. Artificial turf was first invented in 1965 by a group of polymer technologists and was originally known as 'chemgrass'. The prime reason to introduce the synthetic grass in lieu of natural grass is to avoid the initial cost of laying natural turf while the annual costs for an artificial surface are quite high. Indeed, many turf professionals reported an increase in maintenance costs after installing an artificial pitch [38]. Routine mowing not more than one-third of the leaf area, use of proper manures, fertilizers and timely irrigation can keep a lawn healthy very easily. Grasscycling is the act of allowing grass clippings to remain on the lawn after mowing to return nutrients of Nitrogen @ 4\%, Potassium @ 2\%, and Phosphorus@ 0.5\% back to the soil also saves the labor of collecting and bagging clippings and it reduces the "yard waste" component in landfills [26]; [47]. The study by U.S. Environmental Protection Agency (US EPA) estimated that "yard trimmings" including grass clippings, leaves, branches, brush and other plant materials, accounted for $17.9 \%$ of the total municipal solid waste, by percent of weight [45]. Further, artificial turf requires infill such as silicon sand or granulated rubber may carry heavy metals can leach into the water table [40] but natural grass body restock earth water table. In contrast, besides replenishing the ground water table the rain water through a good healthy lawn is filtered often as much as 10 times less acidic than water running off a hard surface [29]. Other studies revealed that turfgrass cover are enough competent to reduce runoff, and therefore enhance soil water infiltration and groundwater recharge [21]; [9]; [37]; [39]; [43]. Finally, the reduced runoff volume from turfgrass covered areas offers the potential to decrease the storm-water management requirements and costly structures used in urban development [44]. Turfgrass ecosystems can support abundant populations of earthworms (Lumbricidae) from 200 to 300 per square meter [11]; [12] owing to their activity increases the amount of macropore space within the soil that results in higher soil water infiltration rates and water-retention 
capacity [23]. The grass body provides a safe, high quality play area for children and elder generations for their move around similarly it furnishes cushion for players engaged in sport activities such as football, cricket, baseball, golf, tennis etc [42]. But synthetic grass can cause skin abrasions and/or burn to a much greater extent due to high temperature during climatic extremes and for its rigid surface. It's also evident that playing on the early-generation artificial surfaces brings a slightly higher risk of injuries, such as turf toe, anterior cruciate ligament injuries, foot lock, turf burn and concussion [41] while natural grass reduces stress levels and even reduce heart rate. Furthermore modern artificial turfs are more permanent installations and not easily removed and replaced for individual sports [40]. Particularly it's not self-repairing while grass has it's self-recuperative potential. Thus, in practice and for most part of countries natural turf turned out to be the better option.

\section{Research Advancement in Natural Grass}

Literally solutions to vanquish the key stumbling block of natural grasses regarding their durability are in great leaps and bounds. Ongoing endeavor of plant breeders to introduce many innovative advanced grass species with ameliorated characteristics such as wear, drought and disease resistance ultimately aggravating natural turf's acceptance [14]. Breeding of grasses initiated on a larger scale in the 1960s, but real focus on sports grass breeding only became more common in the early 1990s [27]. The prime intention of grass breeding counting tolerance to adverse soils- acidic or saline soils, forbearance to extreme weather conditions - high rainfall or low moisture regime, resistance to diseases and insect-pests, greater summer persistence and greater aggressiveness or fast growth [10]. The tremendous progress through biotechnological approach has initiated in the late eighties made remarkable headway at the global level and natural grass solutions are now available that can tackle the problem of growing in different adverse situations like shade, air circulation and persistency in almost every situation. With aid of number of techniques such as embryo rescue, micro-propagation, androgenic haploid plant production and creation of novel variations save time and energy required for conventional methods [27]. The embryo-rescue technique has well been exploited in Lolium-Festuca complex for production of hybrids. Lolium-Dactylis hybrids and many interspecific hybrids in Trifolium have also been developed by this method. Different improvement program has taken up such as improved shade tolerant varieties along with enhanced wear tolerance also for use in stadiums being tested under shady conditions using special tents allow only partial light to pass (eg. velvet bent grass, red creeping fescue, St. Augustine etc.) and improved heat stress tolerant varieties especially areas with acute water shortage like Africa for sports pitches (eg. bermuda grass, red top, red creeping fescue, bahia grass etc.). Over the last 10 years, shoot density has steadily been improved. For sports use, perennial ryegrass varieties exhibited increased density, together with increased strength of recovery, means significant improvement in wear tolerance. Biotechnological approach offers opportunities for creation of novel variations in turf grasses which as such are not possible through conventional methods. In grasses, the success achieved so far has been limited and successful genetic transformation has been reported only in a few perennial grasses, viz. Lolium, Festuca, Agrostis, Dactylis, Paspalum and Dichanthium species. Characterization of germplasm by several molecular techniques viz. restriction fragment length polymorphism (RFLP), amplified fragment length polymorphism (AFLP), random amplified polymorphic DNA (RAPD) and isozymes is one of the most important aspects, especially in the context of the changing scenario with regard to Plant Biodiversity Act. Another important area needing attention of biotechnologist is the development of stress tolerance, both biotic and abiotic, in wide range of turf grass species through gene pyramiding of identified QTLs. Encouraging results have been obtained through the release of large number of improved varieties via grass breeding program at the research institutions under the Indian Council of Agricultural Research (ICAR) and the State Agricultural Universities (SAUs). For example Hima1 and Hima4 are two improved varieties of Fescue grass released in 1998 and 2003 respectively by CSK, HPKV, Palampur adapted for hilly zones. GMG1 (Gujrat Marvel Grass1) another improved one launched by GAU, Banaskantha in 1980 suitable for Gujarat, Central \& western India [5]. Hence, use of upgraded grass cultivars under the correct conditions and management can fetch new innovations and benefits never seen before. 
VII. List of few Warm \& Cool Season Grasses Satisfactory at Indian Climatic Conditions With Abbreviated Remarks [32] Table

\begin{tabular}{|c|c|c|c|c|c|c|c|c|}
\hline \multirow[t]{2}{*}{ Botanical Name } & \multirow[t]{2}{*}{ Common Name } & \multirow[t]{2}{*}{ Leaf Texture } & \multirow[t]{2}{*}{ Sod Forming } & \multirow{2}{*}{$\begin{array}{l}\text { Establishme } \\
\text { nt Rate }\end{array}$} & \multicolumn{4}{|c|}{ Tolerance Capacity } \\
\hline & & & & & High & Medium & Less & Poor \\
\hline Agrostis alba & Red top & Medium & $\begin{array}{c}\text { Bunch grass, } \\
\text { stolons, rhizomes }\end{array}$ & Fast & - & $\begin{array}{l}\text { Drought, cold, salinity, } \\
\text { wear }\end{array}$ & Shade & - \\
\hline Agrostis canina & Velvet bent grass & Fine & Stolons, rhizomes & Fast & Shade, cold & wear & - & - \\
\hline Agrostis paulstris & Creeping bent grass & Fine & Stolons & Medium-fast & Cold, salinity & Shade, drought, heat & - & Wear \\
\hline Agrostis tenuis & Colonial bent grass & Fine & Stolons, rhizomes & Medium-fast & - & $\begin{array}{c}\text { Shade, cold, drought, } \\
\text { heat }\end{array}$ & - & Salinity, wear \\
\hline Axonopus affinis & Carpet grass & Coarse & Stolons & Slow-medium & - & cold & - & $\begin{array}{l}\text { Shade, drought, } \\
\text { salinity, wear }\end{array}$ \\
\hline Cynodon dactylon & Bermuda grass & Fine-Medium & Stolons, rhizomes & Very fast & $\begin{array}{l}\text { Drought, } \\
\text { cold, wear }\end{array}$ & - & - & - \\
\hline Erimochloa ophiuroides & Centipede grass & Medium-Coarse & Stolons & Slow-medium & - & Shade & - & $\begin{array}{l}\text { Salinity, cold, } \\
\text { drought, wear }\end{array}$ \\
\hline Festuca arundinaceae & Tall fescue & Medium-Coarse & Bunches & Slow & Wear & - & - & - \\
\hline Festuca elatior & Meadow fescue & Medium & Individual plants & Slow & \multicolumn{4}{|c|}{ Not common lawn grass } \\
\hline Festuca ovina & Sheep fescue & Fine & Bunches & Slow-medium & Wear & - & - & - \\
\hline Festuca rubra & Red creeping fescue & Fine & Short rhizomes & Medium & Shade & $\begin{array}{l}\text { Drought, cold, heat, } \\
\text { wear }\end{array}$ & - & - \\
\hline Lolium multiflorum & Annual rye grass & Medium & Individual plants & Medium & \multicolumn{4}{|c|}{ Not common lawn grass } \\
\hline Lolium perene & Perennial rye grass & Medium & Bunches & Fast & Wear & Salinity & $\begin{array}{l}\text { Drought, } \\
\text { shade, } \\
\text { cold }\end{array}$ & - \\
\hline Paspalum notatum & Bahia grass & Coarse & Short rhizomes & Medium-slow & - & $\begin{array}{l}\text { Drought, shade, cold, } \\
\text { heat, salinity, wear }\end{array}$ & - & - \\
\hline Poa annua & Annual Blue grass & Fine-Medium & Short stolons & Slow & \multicolumn{4}{|c|}{ Not common lawn grass } \\
\hline Poa compressa & Canada Blue grass & Medium & Individual plants & Slow-medium & - & - & - & Wear \\
\hline Poa pratensis & Kentucky Blue grass & Fine-Medium & Rhizomes & Medium & - & $\begin{array}{l}\text { Drought, cold, heat, } \\
\text { wear }\end{array}$ & $\begin{array}{l}\text { Shade, } \\
\text { salinity }\end{array}$ & - \\
\hline Poa trivalis & Rough blue grass & Fine-Medium & Short stolons & Slow & Cold & $\begin{array}{l}\text { Shade, drought, heat, } \\
\text { salinity }\end{array}$ & - & - \\
\hline Stenophyllum secundation & St. Augustine & Very coarse & Stolons & Fast & Shade & Drought, salinity, wear & - & Cold \\
\hline Zoysia Japonica & Japanese/Korean grass & Fine & Rhizomes, stolons & Slow & Wear & Drought, cold, shade & - & - \\
\hline Zoysia matrella & Manilla grass & Fine & Rhizomes, stolons & Fast & Wear & Drought, cold, shade & - & - \\
\hline Zoysia tenuifolia & Korean grass & Fine & Rhizomes, stolons & Medium & Wear & Drought, cold, shade & - & - \\
\hline
\end{tabular}

\section{Modus-Operandi to Plant Turf-Grass Species}

Adaption to a specific location is the first criteria to consider while selecting a grass species. They differ according to growth habit and other anatomical features that dictate their use and maintenance [24]. Since all landscapes, geographic regions, soil types, altitudes and environmental conditions are not conducive for all grass types, general and specific knowledge about varieties and their requirements for selecting appropriate one are needed. Depending on the species of grass, the type of site and the immediacy of the need for a usable turf, there are few methods of installation such as sodding, seedling, plugging, sprigging and stolonizing [46].

The quickest method for the establishment of turf is soddding [34]. Soddding is the establishment of lawn using sod turf. Sod is grass that is specially cultivated, mowed and cut into strips like pieces of carpet including about 2.5 to $5 \mathrm{~cm}$. (thickness) of roots. Long strips are rolled out and short ones are turfed flat. Although this method is most expensive but least problematic and give instant ground cover [2]. Seeding is the least expensive planting option, but requires longer-term care. Planting seeds of cool-season-grasses in the late summer or early fall results in vigorous growth with strong root. Sprigging and plugging are methods typically reserved for warm-season grasses for which seed is not readily available, such as improved strains of Bermuda grass and St. Augustine grass. It is feasible to plant small areas by either sprigs or plugs. Plugging is the planting of bunch of rooted grass with earth ball in holes followed by tapping the soil around the plug whereas Sprigging is the planting of sprigs, plant sections cut from rhizomes or stolons that includes crowns and roots, at spaced intervals in furrows or holes.

\section{Conclusion}

Turf grass is a popular landscape element seems unlikely that turf grass is so consistently selected by consumers because of its ability to trap and hold ground water, add organic matter to soil, or moderate temperature. Groundwater recharge refers to the retention and use of water - especially rainwater - as it soaks into the ground surface. There is little groundwater retention when the soil surface is bare or when there are impervious surfaces such as streets, driveways, parking lots, and roofs. As a result the rate of surface runoff increases and the time that elapses before runoff decreases [28]. The turf grass areas and the soil beneath create a near ideal medium to purify water as it leaches through the root zone and the soil into underground aquifers. With proper care, lawns will last for many years. Lawns also cool the air near the ground, particularly after they have been watered. Grass improves the soil by stimulating biological life and by creating a more favorable soil structure for plant growth [22]. So it is the fact that artificial turf lacks most of this benefits provided by natural turf grass. But on the other hand, in response to population growth, increasing demand and fluctuations in the availability of water for landscape, the debate between natural turf and artificial turf seems to be leaning on the side of synthetic turfing, but with the assistance of many drought tolerant grass varieties released from the 
breeding programs this daunting obstacle can be easily overcome. In short, natural grass has a good reputation where sustainability and reducing the environmental impact are concerned.

\section{Acknowledgements}

The authors are grateful to DST, INSPIRE Division, New Delhi and University of Calcutta for their continuous support.

[1] A.J. Turgeon, Turfgrass management (Pearson, $9^{\text {th }}$ Edition, 2011).

[2] Anonymous, How thick to cut sod for putting greens, Bulletin of Green Section of USGA, 5 (8), 1925, 172-173.

[3] Anonymous, History of Lawn, Retrieved from: http://www.usna.usda.gov/Education/History\%20of\%20 Lawns. pdf.

[4] Anonymous, Lawn and Turf benefits, Sources: The Professional Landcare Network \& Sustainable Urban Landscape Information Series, Retrieved from: https://landscapeontario.com/lawn-and-turf-benefits.

[5] Anonymous, Forage crops and grasses, Handbook of Agriculture, 39 (New Delhi: Indian Council of Agricultural Research, 2009) 1353-1417.

[6] B. B. James, Turfgrass science and culture (Englehood Cliffts, N.J: Prentice-Hall, 1973).

[7] B. B. James, The environmental protection and beneficial contributions of golf course turfs, Proc. of the World Scientific Congress of Golf, E \& FN Spon, London, 1994

[8] B. Susan, and P. Rebecca, Turfgrass madness: reasons to reduce the lawn in your landscape, Bulletin on Sustainable Landscape Series, Botanic Gradens, University of Delaware. College of Agriculture \& Natural Resources, 2010, 1-15.

[9] C.M. Gross, I.S. Angle, R.L. Hill, and M.S. Welterlen, Runoff and sediment losses from tall fescue under simulated rainfall, $J$. Environ. Qual, 20(3), 1991, 604-607.

[10] C. P. Daniel, D.D. Maria, and S. Masanori. Annual bluegrass weevil. Turfgrass-Integrated Pest Management, 2007, Retrieved from: https://ecommons.cornell.edu/bitstream/handle/1813/42417/ann-bluegrass-weevil-FS-NYSIPM.pdf?sequence=1.

[11] D.A. Potter, B.L. Bridges, and F.C. Gordon, Effect of $\mathrm{N}$ fertilization on earthworm and microarthropod populations in Kentucky bluegrass turf, Agron J, 77, 1985, 367-372.

[12] D.A. Potter, A.J. Powell, and M.S. Smith, Degradation of turfgrass thatch by earthworms (Oligochaeta: Lumbricidae) and other soil invertebrates. J. Econ. Entomol, 83, 1990, 205-211.

[13] E.M. Bauske, and C. Waltz, Influence of Turfgrass on Human Aesthetics and Psychology: a Review, Proc. $3^{\text {rd }}$ Int. Conf. on Landscape and Urban Horticulture, Nanjing, China, 2013, 37-41.

[14] Environmental Protection Acts (EPA), Water sense- Research report on turfgrass allowance, 2009, 1-12, Retrieved from: https://www3.epa.gov/watersense/docs/home_turfgrass-report508.pdf.

[15] E.O. Burt, Summary of south Florida research, Proc. $13^{\text {th }}$ Conf. on Turfgrass Management, Florida, 1965, 160-163.

[16] European Seed Association (ESA), Why choose natural turf- A discussion on natural versus artificial turf for sport and leisure applications, Football \& Stadium Management Magazine, January 2005, Retrieved from: https://www.euroseeds.eu/system/files/publications/files/esa_12.0007.pdf.

[17] European Seed Association (ESA) - Section of Forage Plants and Amenity Grasses (SFG), Why choose natural turf- A discussion on natural versus artificial turf for sports and leisure applications, 2006, Retrieved from: http://www.dlfis.com/upload/esa_2.pdf.

[18] European Seed Association (ESA), Natural Turf- why it remains the natural choice for football, sports and playing surfaces, Euroseeds.Eu, July 2012, Retrieved from: https://www.euroseeds.eu/system/files/publications/files/esa_12.0007.pdf.

[19] F.A. Welton, and J.C. Carroll, Renovation of an old lawn, Journal of American Society of Agronomy, 26 (2), 1999, 486-491.

[20] G. Acquaah, Horticulture principle and Practices (Pearson, $4^{\text {th }}$ Edition, Prentice-Hall, 2002).

[21] H.H. Bennett, Soil Conservation (McGraw-Hill Book Co., Inc. New York, N.Y, 1939).

[22] J.H. Palmer, The nature of growth response to sunlight shown by certain stoloniferous and prostrate tropical plants, New Phytologist, 55, 1956, 346-355.

[23] K.E. Lee, Earthworms- Their ecology and relationships with soil and land use (Academic Press, New South Wales, Australia, 1985).

[24] K. Kelly, and J. Paul, Basic turfgrass care, Utah state university, cooperative extension, 2011, Retrieved from: https://extension.usu.edu/files/publications/publication/HG_517.pdf. p. 1-3.

[25] K. Morris, The national turfgrass research initiative, Inc. National Turfgrass Evaluation Program by National Turfgras Federation, Beltsville Maryland, USA, 2003, 1-18

[26] Koeller \& Company, Potential best management practices- A Report, January 2007, Retrieved from: http://www.allianceforwaterefficiency.org/uploadedFiles/Resource_Center/Library/landscape/synthetic_turf/PBMP-ReportSyntheticTurf.pdf. p- 33-41.

[27] M. Kevin, The national turf grass research initiative (National Turfgrass Federation, Inc. National Turfgrass Evaluation, Beltsville, Maryland, 2003). Retrieved from: http://www.ntep.org/pdf/turfinitiative.pdf.

[28] Natural Lands Trust, A common sense approach to an environmentally friendly lawn, 2007, Retrieved from: https://natlands.org/wp content/uploads/downloads/2013/01/Lawns2007-01.pdf.

[29] P. Julia, and H. Margaret, Green grass and clear water- Water quality friendly lawn care and fertilizer recommendations for northern New England, 1-2, Retrieved from:

https://seagrant.unh.edu/sites/seagrant.unh.edu/files/media/pdfs/extension/lawncare_information_sheet.pdf.

[30] P. Landschott, Turf grass fertilization- A basic guide for professional turfgrass managers (The Pennsylvania State University, College of Agricultural sciences, 2003).

[31] Plantum, Netherlands, Grass really is green- working toward sustainable sports field: Set-up, results and conclusions of research into the environmental impact of grass sports fields. Retrieved from: file:///C:/Users/user/Downloads/Brochure_plantum_carbonfootprint_DEF.pdf.

[32] R. Desh, Floriculture at glance (Kalyani Publishers, 2013).

[33] R. Eliot, and R. Beverly, Environmental Benefits of lawns, The Lawn Institute, 1989, Retrieved from: http://www.thelawninstitute.org/pages/environment/benefits-of-lawn/environmental-benefits-of-lawns/.

[34] R.H. Morrish, and C.M. Harrison, The establishment of various grasses, Journal of the American Society of Agronomy, 40 (2), 1948, 168-179. 
[35] R. T. Gene, and G. Jason, Maintaining Bermuda grass lawns, Texas Agricultural Extension Service, The Texas A \& M University system, 1999, Retrieved from:

http://publications.tamu.edu/TURF_LANDSCAPE/PUB_turf_Maintaining\%20Bermudagrass\%20Lawns.pdf.

[36] Rutgers-the state university of New Jersey, Environment friendly lawn care, 2011, Retrieved from: http://salem.njaes.rutgers.edu/nre/ppt/2011-mangiafico-environ-friendly-lawns-scripted.pdf.

[37] S. Jean, and T. Juang, Effect of bahia grass mulching and covering on soil physical properties and losses of water and soil of slope land (First report), J. Agric. Assoc. China, 105, 1979, 57-66.

[38] S. Rachel, Review of the Impacts of Crumb Rubber in Artificial Turf Applications. University of California, Berkeley Laboratory for Manufacturing and Sustainability, 2010, Retrieved from:

http://www.fieldturf.com/media/BAhbBlsHOgZmSSI8MjAxMi8wOC8wMS8yMi8yNy81MC80NTEvQ3J1bWJfUnViYmVyX1N0 dWR5X0Z1Y18yMDEwLnBkZgY6BkVU/Crumb_Rubber_Study_Feb_2010.pdf.

[39] T.G. Morton, A. J. Gold, and W.M. Sullivan, Influence of overwatering and fertilization on nitrogen losses from home lawns, J. Environ. Qual, 17(1), 1988, 124-130.

[40] The European seed Association (ESA). Natural vs. Artificial turf grass- the facts. Retrieved from: http://www.dlfis.com/upload/natural_vs_artificial.pdf.

[41] The Turfgrass Resource Centre (www.TurfResourceCenter.org), Natural grass and Artificial grass- separating Myths and Facts, 131, Retrieved from: file:///C:/Users/user/Downloads/Artificial\%20Turf\%20Booklet\%202.pdf.

[42] The SAFE foundation, Sports turf - Natural grass athletic fields, Sports turf Managers association and its charitable Foundation, Retrieved from: file://C:/Users/user/Downloads/Sports\%20Turf\%20Natural\%20Grass\%20Athletic\%20Fields.pdf.

[43] T.L. Watschke, and R.O. Mumma, The effect of nutrients and pesticides applied to turf on the quality of runoff and percolating water, Penn State Univ, Environmental Resources Res. Inst. ER 8904, University Park, PA, 1989.

[44] T. Schuyler, Controlling urban runoff: A practical manual for planning and designing urban BMPs, Metropolitan Washington Council of Governments, Washington, D.C, 1987.

[45] United States Environmental Protection Acts (US EPA), Washington, Healthy lawn and environment- caring for your lawn in an environmentally friendly way, 2004, Retrieved from: https://www.epa.gov/sites/production/files/2014-04/documents/healthy_lawn_healthy_environment.pdf.

[46] V.T. Stoutemeyer, Plugs to change turf, Journal of California Agriculture, 8 (2), 1954, 5-6.

[47] W. Alex, and B. Jessica, Sustainability of Natural Landscaping and Artificial Turf: Achieving Water Use and Pesticide Reduction, 2011, Retrieved from:

http://www.water.ca.gov/irwm/grants/docs/Archives/Prop84/Submitted_Applications/P84_Round1_Implementation/San\%20Diego $\%$ 20County\%20Water\%20Authority/Sustainable\%20Landscapes\%20Program/Conventional\%20Lawn\%20Article.pdf.

[48] Wikipedia CD collection, Lawn, Wikipedia Ambassador Program on an Educational Assignment, University of British, Columbia, 2009, Retrieved from: "Gardening - Design - Georgian and Regency". BBC.

[49] Wikipedia CD collection, Lawn, Wikipedia Ambassador Program on an Educational Assignment, University of British, Columbia, 2012, Retrieved from: https://en.wikipedia.org/wiki/Lawn. 